\title{
Influence of Metal-Resistant Staphylococcus aureus Strain K1 on the Alleviation of Chromium Stress in Wheat
}

Fanrong Zeng ${ }^{1}$, Munazza Zahoor ${ }^{2}$, Muhammad Waseem ${ }^{3}{ }^{-1}$, Alia Anayat ${ }^{4}$,

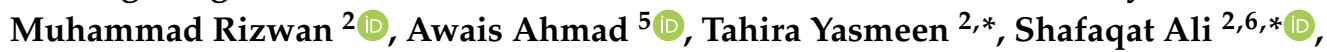
Mohamed A. El-Sheikh ${ }^{7}$, Mohammed Nasser Alyemeni ${ }^{7}$ and Leonard Wijaya ${ }^{7}$

1 School of Agriculture, Yangtze University, 88 Jingmi Road, Jingzhou 434025, China; fanrong.zeng@yangtzeu.edu.cn

2 Department of Environmental Sciences and Engineering, Government College University, Faisalabad 38000, Pakistan; anglicmind5@gmail.com (M.Z.); mrazi1532@yahoo.com (M.R.)

3 Department of Microbiology, Government College University, Faisalabad 38000, Pakistan; muhammad.waseem@gcuf.edu.pk

4 Soil \& Water Testing Lab., Ayub Agricultural Research Institute, Jhang Road, Faisalabad 38000, Pakistan; aliaanayat@gmail.com

5 Department of Chemistry, the University of Lahore, Lahore 54590, Pakistan; awaisahmed@gcuf.edu.pk

6 Department of Biological Sciences and Technology, China Medical University, Taichung 40402, Taiwan

7 Department of Botany and Microbiology, College of Science, King Saud University, Riyadh 11451, Saudi Arabia; melsheikh@ksu.edu.sa (M.A.E.-S.); mnyemeni@ksu.edu (M.N.A.); leon077@gmail.com (L.W.)

* Correspondence: tahirayasmeen@gcuf.edu.pk (T.Y.); shafaqataligill@yahoo.com or shafaqataligill@gcuf.edu.pk (S.A.)

Received: 20 July 2020; Accepted: 26 August 2020; Published: 9 September 2020

\begin{abstract}
Chromium $(\mathrm{Cr})$ is recognized as a toxic metal that has detrimental effects on living organisms; notably, it is discharged into soil by various industries as a result of anthropogenic activities. Microbe-assisted phytoremediation is one of the most emergent and environmentally friendly methods used for the detoxification of pollutants. In this study, the alleviative role of Staphylococcus aureus strain $\mathrm{K} 1$ was evaluated in wheat (Triticum aestivum L.) under $\mathrm{Cr}$ stress. For this, various $\mathrm{Cr}$ concentrations $\left(0,25,50\right.$ and $\left.100 \mathrm{mg} \cdot \mathrm{kg}^{-1}\right)$ with and without peat-moss-based bacterial inoculum were applied in the soil. Results depicted that $\mathrm{Cr}$ stress reduced the plants' growth by causing oxidative stress in the absence of $S$. aureus $\mathrm{K} 1$ inoculation. However, the application of S. aureus $\mathrm{K} 1$ regulated the plants' growth and antioxidant enzymatic activities by reducing oxidative stress and $\mathrm{Cr}$ toxicity through conversion of $\mathrm{Cr}^{6+}$ to $\mathrm{Cr}^{3+}$. The $\mathrm{Cr}^{6+}$ uptake by wheat was significantly reduced in the S. aureus $\mathrm{K} 1$ inoculated plants. It can be concluded that the application of S. aureus $\mathrm{K} 1$ could be an effective approach to alleviate the $\mathrm{Cr}$ toxicity in wheat and probably in other cereals grown under $\mathrm{Cr}$ stress.
\end{abstract}

Keywords: chromium; Staphylococcus aureus; wheat; oxidative stress; antioxidants

\section{Introduction}

Environmental pollution by toxic metals has dramatically increased because of various man-made actions taken while revolutionizing industries and urban life. Although these activities have substantially improved the living standards of humans, they have, at same time, deteriorated the environment [1]. Direct or indirect discharge of sewage and industrial effluent into surface water bodies has resulted in augmentation of chromium (Cr) and other toxic metals in soils [2], causing toxicity to 
plants [3], animals and humans [4]. In agricultural systems, $\mathrm{Cr}$ can easily move to different parts of crops and accumulate there to be later consumed by the animals and humans [5]. Soil contamination by $\mathrm{Cr}$ and other heavy metals impacts biodiversity negatively and badly disturbs the living entities in the soil [6].

Major origins of $\mathrm{Cr}$ contamination are the leather industry [7,8], mining [1], steel industry, paint industry, wood preservatives, volcanic eruption and weathering [9]. Chromium exerts negative effects on plants by reducing the plant height and root growth, interrupting the germination process, causing disproportion in nutrient levels, exerting harmful effects on photosynthesis, retarding soil microbial activities, inhibiting enzyme activity and stimulating the formation of reactive oxygen species (ROS) which result in induction of oxidative stress in plants $[1,10,11]$. Chromium can cause different malfunctions in human biological systems that may lead to the death of affected persons [12-14]. Wastewater effluents from the industries are discharged directly into water bodies that are utilized mostly for irrigation purposes. Farmers have to rely on this untreated contaminated water due to limited resources and inadequate sanitation facilities [15].

A major staple food across the world is wheat (Triticum aestivum L.), which fulfils food requirements of about $50 \%$ of the worldwide population [16]. Amongst wheat-producing countries, Pakistan comes ninth in the world. Wheat subsidizes necessary amino acids, vitamins and minerals, dietary fibers and phytochemicals in our diet [17]. Wheat can accumulate higher Cr concentration in stems followed by leaves and grains [18]. According to the literature, increased heavy metal accumulation in wheat tissues has become a potential source of food chain contamination that can cause serious abnormalities to human biological systems $[19,20]$. Crops may also have the ability to reduce the $\mathrm{Cr}$ from $\mathrm{Cr}^{6+}$ to $\mathrm{Cr}^{3}$. This reduction process is likely to happen in roots as a detoxification mechanism [21]. There are a number of remediation methods used to treat sites contaminated with toxic metals. Presently, scientists have made rampant use of biologically centered techniques to deal with such toxic contaminants in order to remove them from environmental entities, including water, air and soil, or at least make them less damaging to the ecosystem [22]. The phytoremediation technique is a modernized method with a lower budget and environmentally sustainable system [23]; it destroys contaminants by using plants along with their rhizospheric microorganisms. Microbial-assisted phytoremediation helps to deal with toxic heavy metals by stabilizing or transforming them to less toxic forms in carrier materials such as soil, shallow water, sediments or groundwater [24]. Microbes have the capability to modify their genetic sequences in response to variation in environmental factors [25]. In soil polluted with heavy metals, microbes assist the plants by producing various growth-regulating substances, such as organic acids, hormones, siderophores and enzymes, that help in plant growth promotion by involving diverse mechanisms, namely acidification, precipitation, redox reactions and chelation [26]. Likewise, roots excrete beneficial nutrients to support the successful colonization and growth of microbes [26]. Chromium-reducing bacteria have the capability to remediate $\mathrm{Cr}$ toxicity by reducing $\mathrm{Cr}^{6+}$ into $\mathrm{Cr}^{3+}$ in the rhizosphere through bioaccumulation and biosorption mechanisms [27]. Staphylococcus aureus is a Gram-positive, ubiquitous and round-shaped facultative anaerobe that grows in clusters, forming a biofilm on surfaces. It can grow in a range of growth temperature from 7 to $48{ }^{\circ} \mathrm{C}$, with $37^{\circ} \mathrm{C}$ as the optimal temperature for growth [28]. It was isolated from tannery effluent and characterized as a chromium-reducing bacterium. The application of phytoremediation, along with $\mathrm{Cr}$-resistant bacteria for detoxification of $\mathrm{Cr}^{6+}$, has been considered a safe, effective and economical technique over customary techniques $[29,30]$. In this study, the alleviative role of Staphylococcus aureus strain K1 under $\mathrm{Cr}$ stress was evaluated in wheat plants. It was hypothesized that microbes (such as Staphylococcus aureus strain $\mathrm{K} 1$ ) may alleviate $\mathrm{Cr}$ toxicity in wheat by enhancing antioxidant enzymatic activities of wheat while reducing oxidative stress through biotransformation $\left(\mathrm{Cr}^{6+}\right.$ into $\left.\mathrm{Cr}^{3+}\right)$ and biosorption of $\mathrm{Cr}$. 


\section{Materials and Methods}

\subsection{Soil Preparation}

Sandy clay loam soil was brought from nursery and was air-dried without direct sunlight. After air-drying, soil sieving was done by a mesh with a pore size of $2 \mathrm{~mm}$. Soil was then sterilized at a temperature of $121^{\circ} \mathrm{C}$ for 20-30 min for the purpose of removing any kind of contaminant or bacteria that can cause hindrance in further findings [31]. Chromium solutions of different concentrations were prepared from stock solution of $\mathrm{K}_{2} \mathrm{Cr}_{2} \mathrm{O}_{7}$ in the laboratory, and soil was spiked with final $\mathrm{Cr}$ concentrations of $0,25,50$ and $100 \mathrm{mg} \cdot \mathrm{kg}^{-1}$ of soil.

These different concentrations of $\mathrm{Cr}$ were taken to determine the maximum concentration of hexavalent $\mathrm{Cr}$ tolerable by strain $\mathrm{K} 1$. However, in case of $\mathrm{Cr}$ reduction, the lower concentration of $\mathrm{Cr}$ was used due to the fact that $\mathrm{Cr}$ is found in lower concentrations in the natural environment, especially in industrial effluents [31]. The concentrations of $\mathrm{Cr}$ used were similar to those used in the literature and were chosen considering the fact that, in field conditions, we had to establish the reduction ability of this particular strain rather than its maximum potential to survive in response to metal stress [15]. The soil was added in the pots ( $5 \mathrm{~kg}$ soil per pot) with proper mixing following the treatment plan. Electrical conductivity and $\mathrm{pH}$ from saturated soil were determined by making a soil-to-water ratio of 1:25. Soil was extracted with ammonium bicarbonate diethylenetriaminepentaacetic acid (AB-DTPA) solution for the measurement of bioavailable trace elements in the soil [32]. Soil organic matter was determined following the prescribed method [33]. Soil physicochemical characteristics are given in Table 1.

Table 1. Soil characterization of pot experiment.

\begin{tabular}{|c|c|c|}
\hline Soil Properties & Unit & Values \\
\hline Texture Properties & & Sandy Clay Loam \\
\hline $\mathrm{pH}$ & - & 7.71 \\
\hline Sand & $\%$ & 63.7 \\
\hline Clay & $\%$ & 21.9 \\
\hline Silt & $\%$ & 14.4 \\
\hline Electrical Conductivity (EC) & $\mathrm{dSm}^{-1}$ & 4.77 \\
\hline \multicolumn{3}{|l|}{ Soluble Ion Values } \\
\hline $\mathrm{Cl}^{-}$ & $\mathrm{mmol}_{\mathrm{C}} \mathrm{L}^{-1}$ & 7.15 \\
\hline $\mathrm{Ca}^{2+}+\mathrm{Mg}^{2+}$ & $\operatorname{mmol}_{\mathrm{C}} \mathrm{L}^{-1}$ & 14.92 \\
\hline $\mathrm{CO}_{3}^{2-}$ & $\operatorname{mmol}_{C} \mathrm{~L}^{-1}$ & 0.85 \\
\hline $\mathrm{OM}$ & $\%$ & 0.90 \\
\hline CEC & $\mathrm{cmol}_{\mathrm{C}} \mathrm{kg}^{-1}$ & 13.2 \\
\hline $\mathrm{HCO}_{3}^{-}$ & $\operatorname{mmol}_{\mathrm{C}} \mathrm{L}^{-1}$ & 3.84 \\
\hline \multicolumn{3}{|l|}{ Metal Concentration } \\
\hline Available $\mathrm{Cr}^{6+}$ & $\mathrm{mg} \cdot \mathrm{kg}^{-1}$ & 0.04 \\
\hline Available $\mathrm{Zn}^{2+}$ & $\mathrm{mg} \cdot \mathrm{kg}^{-1}$ & 0.72 \\
\hline Available $\mathrm{Cu}^{2+}$ & $\mathrm{mg} \cdot \mathrm{kg}^{-1}$ & 0.23 \\
\hline
\end{tabular}

\subsection{Segregation of Cr-Resistant Bacteria}

A modified method of serial dilution was adopted to isolate the Cr-tolerant bacteria from metal-contaminated industrial effluent [34]. For this, ten-fold serial dilutions $\left(10^{-1}, 10^{-2}, 10^{-3}\right.$ and $\left.10^{-4}\right)$ were prepared from samples of collected wastewater using sterilized distilled water [34]. Then, $0.1 \mathrm{~mL}$ from each dilution was added to petri plates having Tryptic Soy Agar complemented with $0.5 \mathrm{mM}$ $\mathrm{Cr}^{6+}$. Morphologically different colonies were picked and transferred to petri plates supplemented with gradually elevated levels $(0.0,0.5,2.5,5.0,10.0,15.0,20,22$ and $23 \mathrm{mM})$ of $\mathrm{Cr}^{6+}$ [35]. The bacteria 
that showed maximum resistance to the highest concentration of hexavalent $\mathrm{Cr}$ were selected for use in further studies.

\subsection{Bacterial Identification}

Molecular characterization was carried out through the amplification of $16 \mathrm{~S}$ rDNA gene via polymerase chain reaction (PCR) using the following universal primers: 27F (5'-AAACTCAAATGAATTGACGG-3') and 1492R (5'-ACGGGCGGTGTGTAC-3') [36]. For genomic DNA extraction, Favorgen DNA extraction kit was used following the manufacturer's guideline. The initial denaturation temperature was set at $94{ }^{\circ} \mathrm{C}$ for a period of $5 \mathrm{~min}$, and this was followed by 40 recurring cycles of denaturizing DNA at $94{ }^{\circ} \mathrm{C}$ for $45 \mathrm{~s}$, annealing at $53{ }^{\circ} \mathrm{C}$ for $45 \mathrm{~s}$ and elongation at $72{ }^{\circ} \mathrm{C}$ for $60 \mathrm{~s}$. Final extension was set at $72{ }^{\circ} \mathrm{C}$ for $10 \mathrm{~min}$, and this was followed by temperature being held at $4{ }^{\circ} \mathrm{C}$ [37]. PCR product $(5 \mu \mathrm{L})$ was loaded in gel wells, and the reaction was allowed to complete; the product was then visualized using Gel Documentation System (Slite $200 \mathrm{~W}$ ) under ultraviolet light [37]. After validation, $30 \mu \mathrm{L}$ PCR product was delivered to Macrogen (Seoul, Korea) for the purpose of sequencing. ChormasPro (v1.7.1) software was used for correction of sequences that were submitted to GenBank for accession number. A phylogenetic tree was constructed by downloading similar partial 16S rDNA gene sequences from the NCBI BLAST database with the help of computer software MEGA (v7.0.) [38].

\subsection{Bacterial Inoculum Preparation}

In order to obtain pure inoculum of $S$. aureus strain $\mathrm{K} 1$, an individual isolated colony was inoculated in $250 \mathrm{~mL}$ sterilized nutrient broth and incubated at $150 \mathrm{rpm}$ on orbital rotary shaker for $48 \mathrm{~h}\left(\right.$ at $\left.37^{\circ} \mathrm{C}\right)$. The pure culture was harvested via centrifugation at $6000 \times \mathrm{g}$ for $10 \mathrm{~min}$, and the supernatant was discarded. The pellet was washed with sterilized distilled water and resuspended in $100 \mathrm{~mL}$ of normal saline $(0.85 \% \mathrm{NaCl})$ solution. Overall, cell density for the inoculum was maintained at $1 \times 10^{8} \mathrm{CFU} \mathrm{mL}^{-1}$ [39].

\subsection{Seed Coating and Pot Experiment}

For this study, seeds of wheat variety Sehar were taken from Ayub Agriculture Research Institute, Faisalabad, Pakistan. Seeds were first washed thoroughly with distilled water, and this was followed by surface sterilization using $10 \%$ hydrogen peroxide $\left(\mathrm{H}_{2} \mathrm{O}_{2}\right)$ for $30 \mathrm{~min}$ [40]. The sterilized seeds were immersed in double volume of bacterial suspension $\left(1 \times 10^{8} \mathrm{CFU} \mathrm{mL} \mathrm{mL}^{-1}\right)$ and kept at $37 \pm 2{ }^{\circ} \mathrm{C}$ on a rotary shaker $(90 \mathrm{rpm})$ for $2 \mathrm{~h}$. To facilitate the attachment of bacterial inoculum to the seeds, carboxymethyl cellulose (CMC) $(2 \%)$ was added to the suspension as a sticking agent. Seeds were dried under shade after $2 \mathrm{~h}$ of inoculation for further experimental use. Uninoculated sterilized seeds were used as control. Clay and peat moss in equal parts (1:1) were mixed and the seeds were added to this mixture, which was shaken well for proper coating and incubated overnight in the dark. The completely randomized design had a total of eight treatments, with three replicates for each treatment. A total of eight seeds per pot were sown, and thinning was performed to result in four seedlings per pot after 3 weeks of seed germination.

\subsection{Treatments}

The experiment was conducted in plastic pots using different concentrations of $\mathrm{Cr}(0,25,50$ and $\left.100 \mathrm{mg} \cdot \mathrm{kg}^{-1}\right)$ in the presence and absence of bacterial inoculation. Different treatments were as follows: T1 (Control), $0 \mathrm{mg} \cdot \mathrm{kg}^{-1} \mathrm{Cr}$; T2, $25 \mathrm{mg} \cdot \mathrm{kg}^{-1} \mathrm{Cr}$; T3, $50 \mathrm{mg} \cdot \mathrm{kg}^{-1} \mathrm{Cr}$; T4, $100 \mathrm{mg} \cdot \mathrm{kg}^{-1} \mathrm{Cr} ; \mathrm{T} 5,0 \mathrm{mg} \cdot \mathrm{kg}^{-1}$ $\mathrm{Cr}+$ S. aureus $\mathrm{K} 1 ; \mathrm{T} 6,25 \mathrm{mg} \cdot \mathrm{kg}^{-1} \mathrm{Cr}+$ S. aureus $\mathrm{K} 1 ; \mathrm{T} 7,50 \mathrm{mg} \cdot \mathrm{kg}^{-1} \mathrm{Cr}+$ S. aureus $\mathrm{K} 1 ; \mathrm{T} 8,100 \mathrm{mg} \cdot \mathrm{kg}^{-1}$ $\mathrm{Cr}+$ S. aureus $\mathrm{K} 1$.

\subsection{Plant Harvesting}

At 135 days after seed sowing, plants were harvested at maturity. The height and spike lengths of plants were measured with a meter rod. Shoots, roots, spikes and grains were separated properly. 
Then, $0.1 \mathrm{M} \mathrm{HCl}$ was used to remove the metals from the root surface, and the roots were washed with distilled water. Samples of roots and shoots were kept in a hot air oven $\left(70{ }^{\circ} \mathrm{C}\right)$ for a period of $72 \mathrm{~h}$. Afterwards, dry weight was recorded and samples were crushed to small pieces and processed for further analyses.

\subsection{Determination of Chlorophyll Contents and Gas Exchange Parameters}

At 8 weeks after seed germination, fresh leaf samples were taken to determine chlorophyll contents using acetone $(85 \% \mathrm{v} / \mathrm{v})$ for pigment extraction. These leaf samples were kept in the dark at $4{ }^{\circ} \mathrm{C}$ for $24 \mathrm{~h}$. Centrifugation of samples was done to get the supernatant. Absorbance was recorded by spectrophotometer at three different wavelengths $(470,647$ and $664.5 \mathrm{~nm})$, and final chlorophyll contents were calculated by following the prescribed method [41]. Photosynthetic rate, transpiration rate and stomatal conductance of samples were recorded 8 weeks after seed germination on a fully sunny day using an infrared gas analyzer (IRGA, LCA-4, Analytical Development Company, Hoddesdon, UK).

\subsection{Determination of Reactive Oxygen Species and Antioxidant Enzyme Activities}

At 2 months after seed sowing, fresh leaves of plants were sampled for the estimation of reactive oxygen species (ROS) through the assessment of electrolyte leakage (EL) and the contents of malondialdehyde (MDA) and hydrogen peroxide $\left(\mathrm{H}_{2} \mathrm{O}_{2}\right)$. Additionally, the activities of enzymes such as superoxide dismutase (SOD), peroxidase (POD), catalase (CAT) and ascorbate peroxidase (APX) were assessed. For the EL estimation, distilled water tubes were used to place leaf samples. Samples were autoclaved at $32{ }^{\circ} \mathrm{C}$ for period of $2 \mathrm{~h}$, and the observed EC of the solution was termed as $\mathrm{EC}_{1}$. Afterwards, this solution was autoclaved at $121^{\circ} \mathrm{C}$ for $20 \mathrm{~min}$ to measure $\mathrm{EC}_{2}$, and finally EL was calculated using the following equation as described by Dionisio-Sese and Tobita [42]:

$$
\mathrm{EL}=\left(\mathrm{EC}_{1} / \mathrm{EC}_{2}\right) \times 100
$$

The concentration of MDA was measured using the method of Heath and Packer (1968) as modified by Dhindsa et al. [43] and Zhang and Kirham [44]. Hydrogen peroxide was recorded through homogenization of samples in phosphate buffer $50 \mathrm{mM}(\mathrm{pH}$ 6.5) and centrifugation followed by addition of $20 \% \mathrm{H}_{2} \mathrm{SO}_{4}(v / v)$. Samples were centrifuged once more for $15 \mathrm{~min}$, and readings were taken by spectrophotometer at $410 \mathrm{~nm}$ absorbance [45]. A spectrophotometer was utilized to record the activities of antioxidant enzymes such as SOD, POD, CAT and APX. Fresh leaf samples were crushed in liquid nitrogen $\left(\mathrm{N}_{2}\right)$, and $0.05 \mathrm{M}$ phosphate buffer $(\mathrm{pH} 7.8)$ was utilized for the purpose of standardization. This was followed by centrifugation at $4{ }^{\circ} \mathrm{C}$ on $12,000 \times g$ for a period of $10 \mathrm{~min}$. Supernatant was collected for the sake of antioxidant enzyme activity measurements. The method of Zhang [46] was employed to measure SOD and POD activities, while the Aebi method [47] was used for CAT activity. APX contents were estimated using the method of Nakano and Asada [48].

\subsection{Estimation of $\mathrm{Cr}$ Contents in Plants}

Digestion of dry shoot and root samples was performed for $1 \mathrm{~g}$ of each sample in 4:1 $(v / v)$ ratio of $\mathrm{HNO}_{3}: \mathrm{HClO}_{4}$ as described by Rehman et al. [49]. Finally, the digested samples were run on an atomic absorption spectrophotometer for the estimation of $\mathrm{Cr}$ concentrations in the processed samples.

\subsection{Statistical Analysis}

The IBM SPSS Statistics for Windows, Version 21.0, was used for the data analyses, using the analysis of variance (ANOVA) tool at a 5\% probability level. Tukey's HSD post hoc test was performed for multiple comparison of triplicates.

\section{Results}

The current study was envisaged to assess the capability of metal-resistant Staphylococcus aureus strain $\mathrm{K} 1$ to ameliorate the Cr stress in wheat plants. 


\subsection{Growth Characteristics of Isolate K1}

The bacterial strain $\mathrm{K} 1$, capable of tolerating a Cr concentration of up to $22 \mathrm{mM}$, was selected for further studies. Morphologically, it is characterized by Gram-positive cocci $(\approx 1 \mu \mathrm{m})$ with yellowish golden color. Chemically, it is oxidase- and coagulase-negative and catalase-positive (Table 2). The BLASTn investigation showed that it has a close resemblance (99\%) to Staphylococcus aureus strain ATCC 12600 (NR_115606.1) and Staphylococcus aureus strain NBRC 100910 (MG971399.1). The similar 16S rDNA gene sequences from GenBank were used to carry out phylogenetic analysis, which also confirmed that the isolate K1 belongs to Staphylococcus aureus; therefore, it was named Staphylococcus aureus strain K1 (KX685332). This was done in order to remain confident that the bacterial strain used in this study was Staphylococcus aureus strain K1, as culture media can sometimes be contaminated with other bacteria.

Table 2. Biochemical and morphological characteristics of S. aureus strain K1.

\begin{tabular}{ccc}
\hline Sr. No. & Characteristic & Staphylococcus aureus K1 \\
\hline 1 & Morphology & Convex, round \\
2 & Color & Yellowish, golden \\
3 & Gram-reaction & $+\mathrm{ve}$ \\
4 & Catalase & $+\mathrm{ve}$ \\
5 & Coagulase plasma reaction & $-\mathrm{ve}$ \\
\hline
\end{tabular}

\subsection{Effect of S. aureus K1 Contact Time on Chromium $\left(\mathrm{Cr}^{6+}\right)$ Reduction}

Staphylococcus aureus $\mathrm{K} 1$ exhibited optimum growth at $\mathrm{pH} 8$ and $35^{\circ} \mathrm{C}$. Under optimum growth conditions, the effect of contact time on bacterial ability to reduce the hexavalent $\mathrm{Cr}$ in the medium was observed. It was observed that the $\mathrm{Cr}$ reduction of $S$. aureus $\mathrm{K} 1$ increased with increasing contact time (Figure 1). It was found that $26 \%, 45 \%, 71 \%, 80 \%$ and $99 \% \mathrm{Cr}^{6+}$ (initial metal concentration $=1 \mathrm{mM}$ ) was removed from the medium by Staphylococcus aureus K1 after 2, 4, 8, 16 and $24 \mathrm{~h}$ of incubation, respectively (Figure 1).

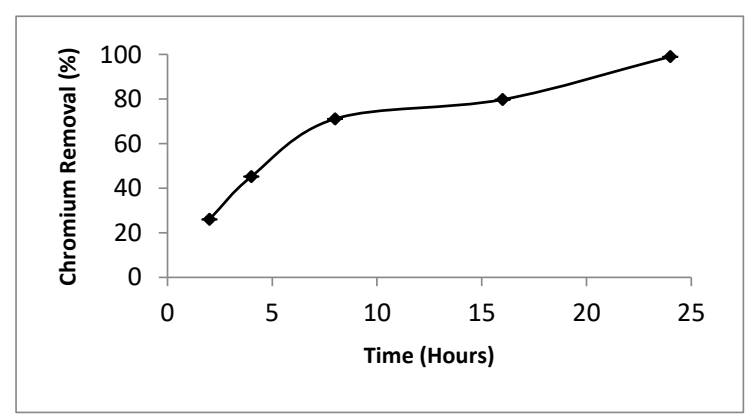

Figure 1. The impact of contact time (hours) impact on the Cr removal ability of Staphylococcus aureus K1.

\subsection{Effect of S. aureus K1 on Plant Growth Promotion}

Chromium stress substantially decreased the growth of wheat plants. A significant reduction in the length of shoots $(31.18 \%)$, roots $(32.02 \%)$ and spikes $(40.70 \%)$ and the dry weight of shoots (34.29), roots (44.17) and grains (31.06\%) of the plant was observed at $100 \mathrm{mg} \cdot \mathrm{kg}^{-1} \mathrm{Cr}$ concentration alone as compared to S. aureus $\mathrm{K} 1$ inoculated seeds $+100 \mathrm{mg} \cdot \mathrm{kg}^{-1} \mathrm{Cr}$ concentration (Figure 2). A significant change in shoot and root length was observed in inoculated plants as compared to uninoculated plants at all levels of $\mathrm{Cr}$. Wheat plants stressed with $50 \mathrm{mg} \cdot \mathrm{kg}^{-1}$ of $\mathrm{Cr}$ showed an observable reduction in growth attributes; however, this decrease was minimized in inoculated plants compared to uninoculated plants, as shown in Figure 2. The growth was gradually decreased when the $\mathrm{Cr}$ concentration in the growth medium increased from 25 to $100 \mathrm{mg} \cdot \mathrm{kg}^{-1}$ (Figure 2A-D). Moreover, the maximum growth reduction was noticed with $100 \mathrm{mg} \cdot \mathrm{kg}^{-1}$ of $\mathrm{Cr}$ stress. The data regarding plant growth attributes 
indicated that inoculation with $\mathrm{S}$. aureus $\mathrm{K} 1$ significantly improved the wheat growth and dry biomass under $\mathrm{Cr}$ stress conditions.
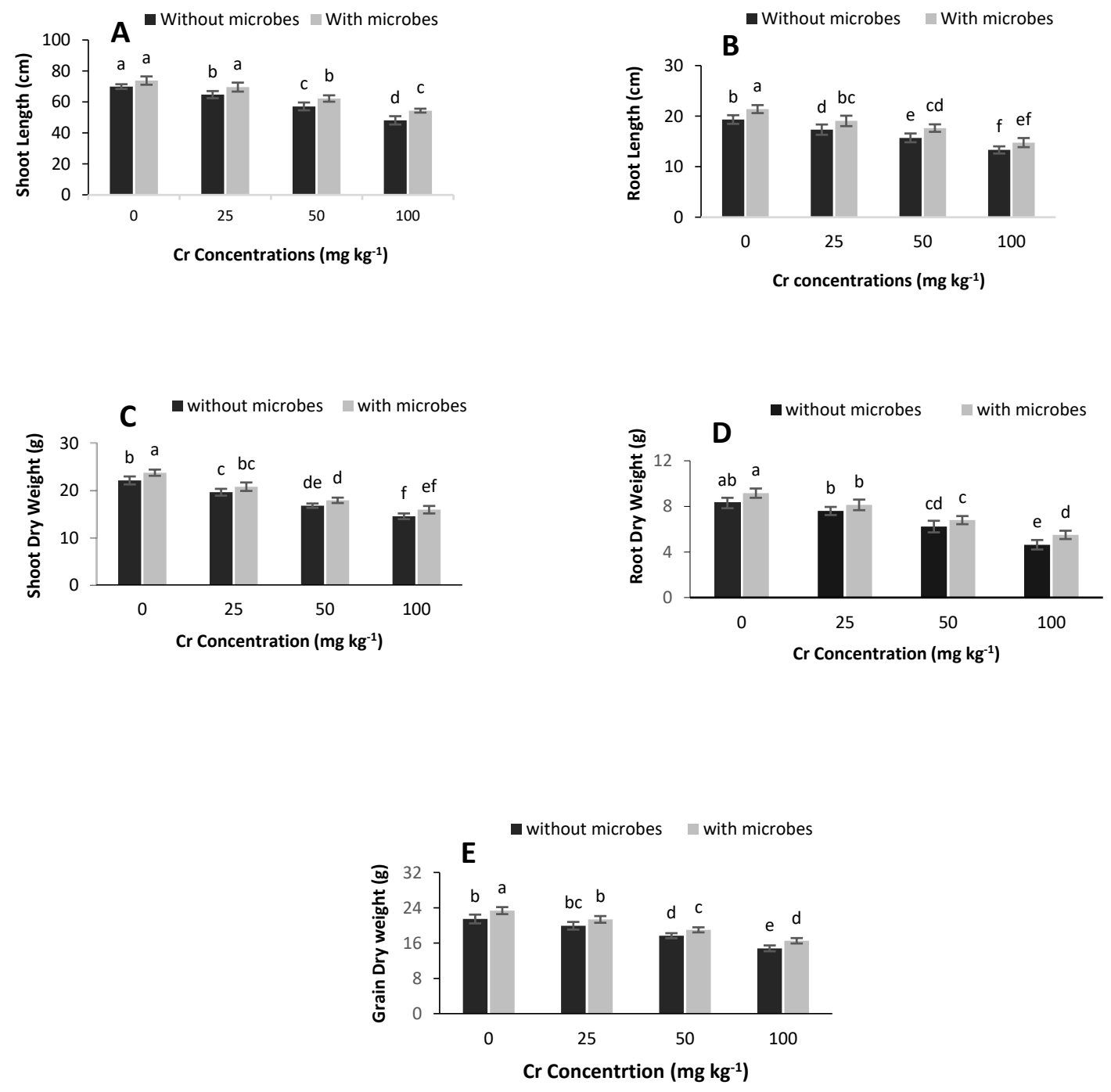

Figure 2. Influence of the different $\mathrm{Cr}$ levels $\left(0,25,50,100 \mathrm{mg} \cdot \mathrm{kg}^{-1}\right)$, with and without peat-moss-based microbial inoculation, on length of shoot (A) and root (B), dry weight of shoot (C) and root (D) and grain dry weight (E) of wheat. Bars indicate the mean of three replicates with standard deviation (SD). Different bars with lowercase letters show noteworthy changes among various treatments at $p<0.05$.

\subsection{IRGA Parameters and Chlorophyll Contents}

IRGA parameters such as transpiration rate, stomatal conductance and photosynthetic rate gradually reduced under increased $\mathrm{Cr}$ concentrations alone. The transpiration rate was greater at $25 \mathrm{mg} \cdot \mathrm{kg}^{-1}$ of $\mathrm{Cr}$ stress and decreased with increasing $\mathrm{Cr}$ stress levels at concentrations from 50 to $100 \mathrm{mg} \cdot \mathrm{kg}^{-1}$. Without microbial inoculation, transpiration rate decreased by $12 \%, 21 \%$ and $32 \%$ under 25, 50 and $100 \mathrm{mg} \cdot \mathrm{kg}^{-1} \mathrm{Cr}$ stress, respectively, as compared to control (Figure 3A). Similarly, stomatal conductance and photosynthetic rate in uninoculated plants also reduced with increasing $\mathrm{Cr}$ concentrations. Stomal conductance decreased by $9 \%, 25 \%, 45 \%$ and photosynthetic rate decreased by $12 \%, 25 \%$ and $46 \%$ under 25,50 and $100 \mathrm{mg} \cdot \mathrm{kg}^{-1} \mathrm{Cr}$ stress, respectively, as shown in Figure 3B,C. These results explain the effective role of bacterial inoculation in improving gas exchange attributes in Cr-stressed wheat plants by comparing uninoculated plants. Similarly, chlorophyll a contents decreased by $9.40 \%, 26.21 \%$ and $40.08 \%$ in inoculated plants and by $10.66 \%, 28.02 \%$ and $41.87 \%$ in uninoculated plants under 25, 50 and $100 \mathrm{mg} \cdot \mathrm{kg}^{-1} \mathrm{Cr}$ stress, respectively, as shown in Figure 3D. 
On the other hand, as compared to untreated control, chlorophyll b was reduced by $15.36 \%, 27.27 \%$ and $40.80 \%$ in uninoculated wheat plants and by $14.44 \%, 27.24 \%$ and $40.63 \%$ in inoculated wheat plants under 25, 50 and $100 \mathrm{mg} \cdot \mathrm{kg}^{-1} \mathrm{Cr}$ stress, respectively, as shown in Figure 3E. A gradual decrease in carotenoid contents was also observed in inoculated and uninoculated plants with increasing level of Cr stress, where inoculated plants showed $6 \%, 19 \%$ and $27 \%$ reduction in carotenoid contents while uninoculated plants showed $9 \%, 19 \%$ and $28 \%$ reduction under 25,50 and $100 \mathrm{mg} \cdot \mathrm{kg}^{-1} \mathrm{Cr}$ stress, respectively (Figure 3F)
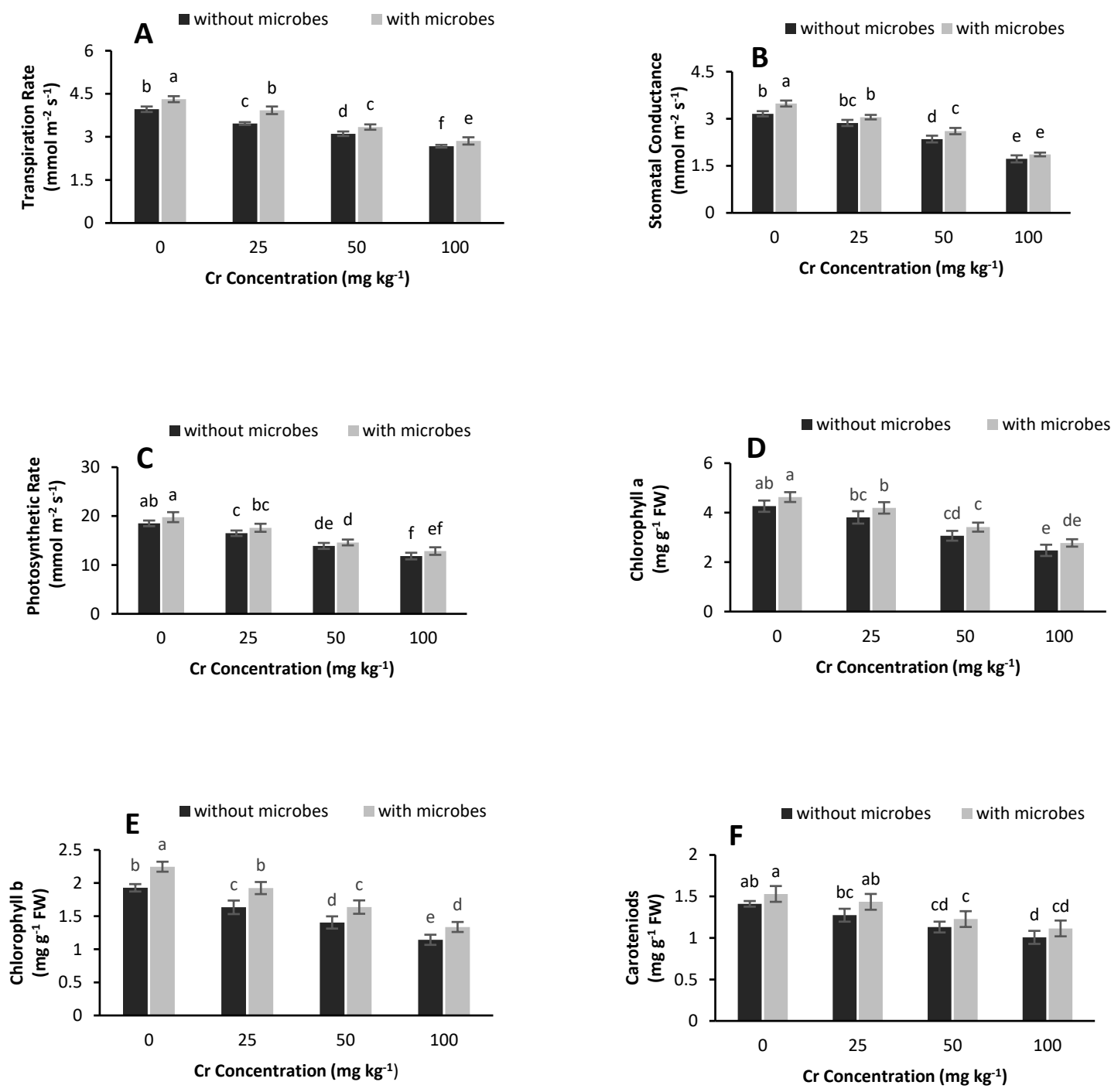

Figure 3. Influence of the different $\mathrm{Cr}$ levels $\left(0,25,50,100 \mathrm{mg} \cdot \mathrm{kg}^{-1}\right)$, with and without peat-moss-based microbial inoculation, on transpiration rate (A), stomatal conductance (B), photosynthetic rate (C), chlorophyll a (D), chlorophyll b (E) and carotenoids (F) of wheat plants. Bars indicate the mean values and standard deviation of three replicates. Different bar letters show significant changes among various treatments at $p<0.05$.

\subsection{Estimation of EL, $M D A$ and $\mathrm{H}_{2} \mathrm{O}_{2}$}

A substantial increase in EL was noted in both roots and shoots of wheat plants under Cr stress, as shown in Figure 4A,B. Uninoculated wheat plants showed more EL in leaves and roots under all Cr levels $\left(0,25,50\right.$ and $\left.100 \mathrm{mg} \cdot \mathrm{kg}^{-1}\right)$ as compared to inoculated plants. EL in uninoculated leaves was increased by $17.98 \%, 36.40 \%$ and $56.52 \%$ and EL in uninoculated roots increased by $9 \%, 32 \%$ and $53 \%$ under 25,50 and $100 \mathrm{mg} \cdot \mathrm{kg}^{-1} \mathrm{Cr}$, respectively. On the other hand, inoculation with S. aureus $\mathrm{K} 1$ 
increased EL in leaves by $15.83 \%, 33.26 \%$ and $55.90 \%$ and in roots by $13 \%, 33 \%$ and $56 \%$, under 25 , 50 and $100 \mathrm{mg} \cdot \mathrm{kg}^{-1} \mathrm{Cr}$, respectively (Figure $4 \mathrm{~A}, \mathrm{~B}$ ).
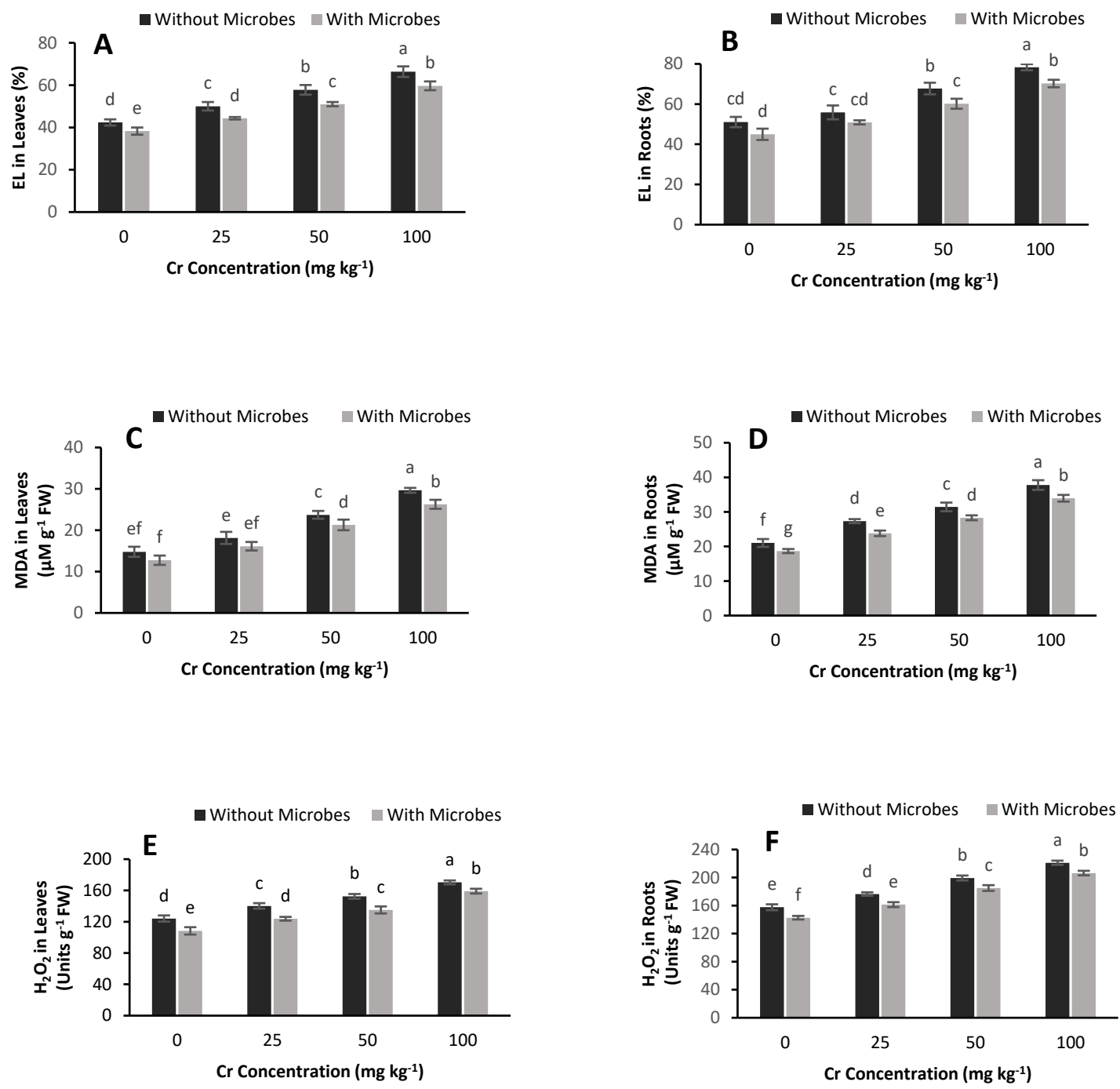

Figure 4. Influence of the different $\mathrm{Cr}$ levels $\left(0,25,50,100 \mathrm{mg} \cdot \mathrm{kg}^{-1}\right)$, with and without peat-moss-based microbial inoculation, on EL in leaves (A), EL in roots (B), MDA in leaves (C), MDA in roots (D), $\mathrm{H}_{2} \mathrm{O}_{2}$ in leaves (E) and $\mathrm{H}_{2} \mathrm{O}_{2}$ in roots $(\mathbf{F})$ of wheat plants. Bars indicate the mean values and standard deviation of three replicates. Different bar letters show significant changes among various treatments at $p<0.05$.

There was a noticeable increase in MDA content of leaves, showing lipid peroxidation due to high level of $\mathrm{Cr}$ stress, as shown in Figure 4C,D. Maximum MDA contents were observed in leaves and roots of uninoculated plants under $100 \mathrm{mg} \cdot \mathrm{kg}^{-1} \mathrm{Cr}$ stress as compared to their respective controls. However, inoculation with S. aureus $\mathrm{K} 1$ reduced MDA content in all the plants of varying level of $\mathrm{Cr}$ stress compared to uninoculated plants. Likewise, a gradual rise in $\mathrm{H}_{2} \mathrm{O}_{2}$ of wheat leaves was observed with increasing levels of $\mathrm{Cr}$ (Figure 4E,F). Furthermore, a noteworthy decrease in $\mathrm{H}_{2} \mathrm{O}_{2}$ content was observed in S. aureus K1 inoculated plants, both Cr-stressed and control.

\subsection{Effect of S. aureus on Antioxidant Enzyme Activities}

The findings revealed that SOD activity in leaves and roots was significantly higher at the $25 \mathrm{mg} \cdot \mathrm{kg}^{-1} \mathrm{Cr}$ level but gradually decreased with increasing $\mathrm{Cr}$ levels, both in uninoculated and inoculated plants. SOD activity increased by $19.59 \%, 5.22 \%$ and $6.98 \%$ in uninoculated plant leaves and 
by $17.58 \%, 5.22 \%$ and $3.08 \%$ in uninoculated plant roots under 25,50 and $100 \mathrm{mg} \cdot \mathrm{kg}^{-1} \mathrm{Cr}$ treatments, respectively. However, inoculation with $S$. aureus K1 enhanced the SOD activity by $24.71 \%, 9.64 \%$ and $3.51 \%$ in leaves and $20.83 \%, 9.49 \%$, and $4.34 \%$ in roots under 25,50 and $100 \mathrm{mg} \cdot \mathrm{kg}^{-1} \mathrm{Cr}$, respectively (Figure 5A,B). As compared to noncontaminated treatments (control), a decline in the CAT activity was observed under $\mathrm{Cr}$ contamination (Figure 5C,D). Inoculation with $\mathrm{S}$. aureus $\mathrm{K} 1$ provoked a substantial increase in the activity of the CAT enzyme in wheat leaves (Figure 5C). CAT activity in roots also improved (114.31 Units. ${ }^{-1} \mathrm{FW}$ ) under bacterial inoculation as compared to uninoculated plants (102.66 Units $\mathrm{g}^{-1} \mathrm{FW}$ ) at $25 \mathrm{mg} \cdot \mathrm{kg}^{-1} \mathrm{Cr}$ (Figure 5D). Moreover, abridged CAT activity was noticed at the highest level of Cr stress $\left(100 \mathrm{mg} \cdot \mathrm{kg}^{-1}\right)$; activity at this level was increased by $5.52 \%$ in leaves and $3.63 \%$ in roots for uninoculated plants, while inoculated plants showed increase of $5.06 \%$ in leaves and $1.37 \%$ in roots, as shown in Figure 5C,D. The POD activity substantially $(p<0.05)$ increased due to addition of $\mathrm{Cr}$ as compared to control (Figure 5E,F). There was a noticeable reduction in POD activity in leaves under bacterial inoculation with S. aureus strain K1 $(22.27 \%, 11.99 \%$ and $0.21 \%)$ as compared to uninoculated treatments $(21.63 \%, 10.12 \%$ and $2.92 \%$ ) (Figure $5 \mathrm{E}$ ). There was a substantial increase in the activity of the APX enzyme observed under Cr stress in wheat plants, as shown in Figure 5G,H. There was increase in APX activity in plant shoots and roots, with the maximum production occurring at the $\mathrm{Cr}$ concentration of $25 \mathrm{mg} \cdot \mathrm{kg}^{-1}$, and the APX activity decreased at the highest $\mathrm{Cr}$ level in the growth medium (Figure 5G,H). Furthermore, the maximum APX activity was observed in roots without inoculation at $\mathrm{Cr}$ concentration of $25 \mathrm{mg} \cdot \mathrm{kg}^{-1}$, as shown in Figure $5 \mathrm{H}$.
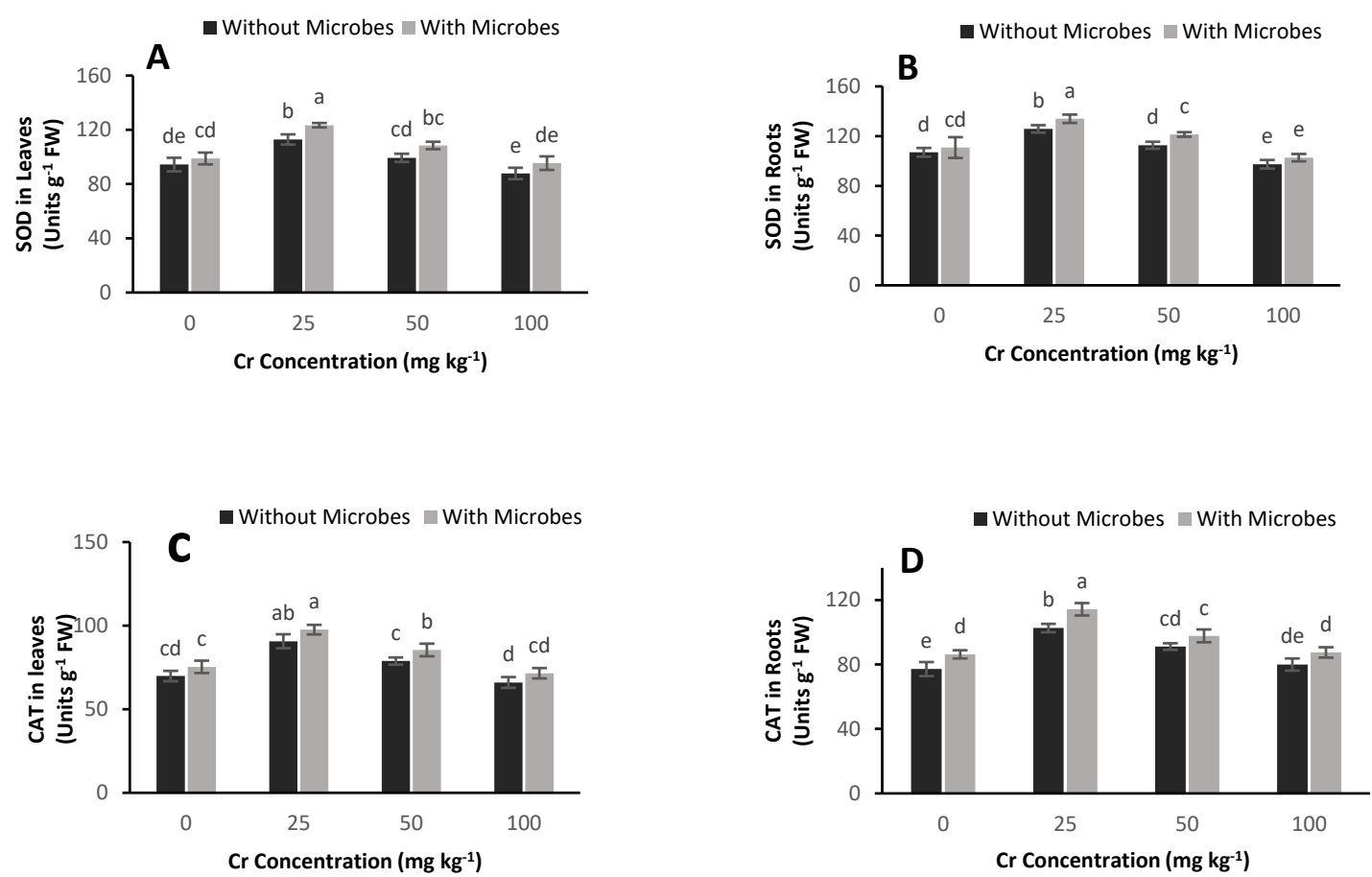

Figure 5. Cont. 

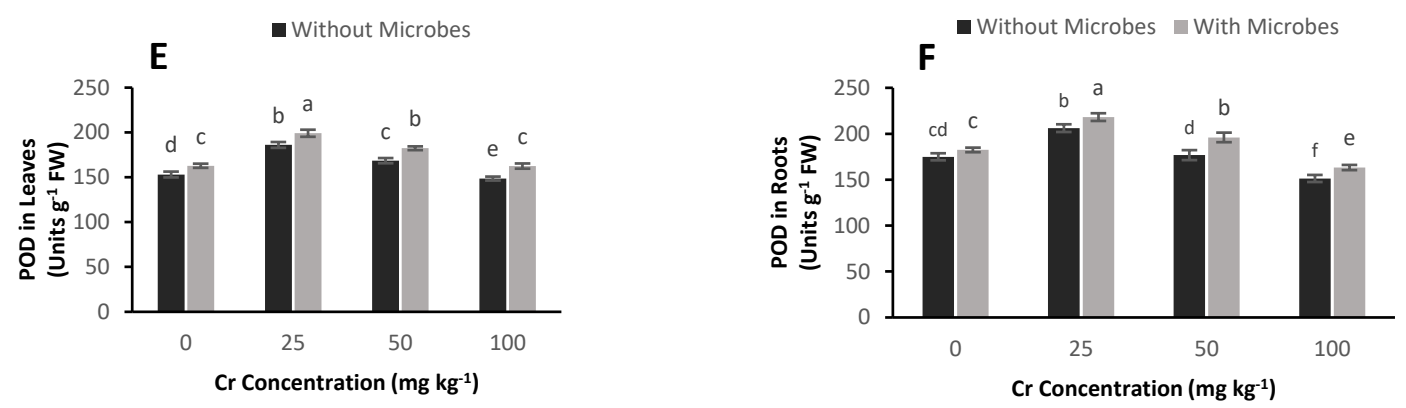

G

- Without Microbes With Microbes

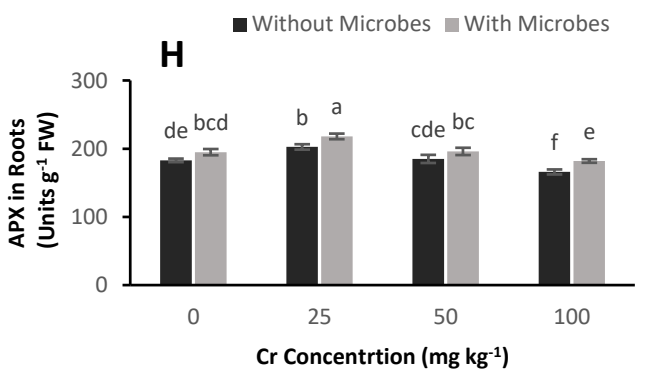

Figure 5. Influence of the different $\mathrm{Cr}$ levels $\left(0,25,50,100 \mathrm{mg} \cdot \mathrm{kg}^{-1}\right)$, with and without peat-moss-based microbial inoculation, on SOD in leaves (A), SOD in roots (B), CAT in leaves (C), CAT in roots (D), POD in leaves (E), POD in roots (F), APX in leaves $(\mathbf{G})$ and APX in roots $(\mathbf{H})$ of wheat plants. Bars indicate the mean values with standard SD of three replicates. Different bar letters show significant changes among various treatments at $p<0.05$.

\subsection{Cr Accumulation in Plants}

The data regarding $\mathrm{Cr}$ accumulation in shoots and roots of the wheat plants are shown in Figure 6A,B. With increasing concentration of applied $\mathrm{Cr}$, a gradual increase in $\mathrm{Cr}$ concentrations was observed in roots and shoots in a dose-additive manner. In addition, inoculation of S. aureus $\mathrm{K} 1$ significantly decreased the $\mathrm{Cr}$ concentrations both in shoots and roots as compared to uninoculated plants.

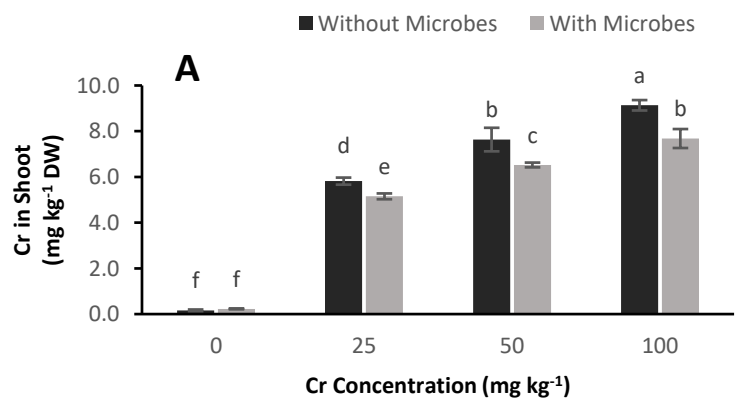

Figure 6. Cont. 


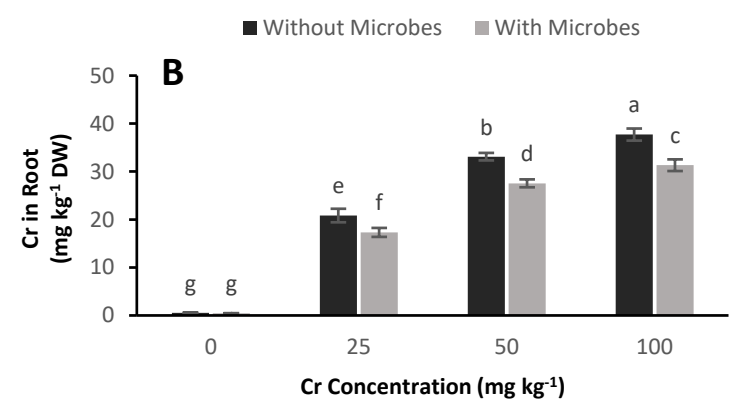

Figure 6. Influence of the different $C r$ levels $\left(0,25,50,100 \mathrm{mg} \cdot \mathrm{kg}^{-1}\right)$, with and without peat-moss-based microbial inoculation, on $\mathrm{Cr}$ concentrations in shoots (A) and roots (B) of wheat plants. Bars indicate the mean values with standard SD of three replicates. Different bar letters show significant changes among various treatments at $p<0.05$.

\section{Discussion}

The major objective of our research was to appraise the effectiveness of Staphylococcus aureus $\mathrm{K} 1$ treatment in reducing the toxic effects of $\mathrm{Cr}$ stress in wheat plants. An indigenous bacterial strain, Staphylococcus aureus K1 (GenBank accession no. KX685332), capable of tolerating up to $22 \mathrm{mM}$ of $\mathrm{Cr}^{6+}$ was isolated from a metal-polluted environment. Numerous research studies with similar metal-tolerant bacterial isolations from metal-contaminated sites have been reported [35,50,51]. Our results also supported the findings of Mustapha and Halimoon [52], who isolated a total of 21 isolates from electroplating industries and reported that merely 5 of them were Cr-tolerant (up to $50 \mathrm{mg} \cdot \mathrm{L}^{-1}$ ). The results of the current study show that $\mathrm{S}$. aureus $\mathrm{K} 1$ increased plant growth parameters under $\mathrm{Cr}$ metal stress (Figure 2).

\subsection{Detoxification of Metals by S. aureus K1}

Microbes have a number of metal resistance mechanisms involving chromosomes, transposon-encoded genes or plasmids. These mechanisms are mostly plasmid-facilitated and show resistance to some particular anion or cation [53]. Metals can have different impacts inside cells depending upon their concentration [53]; once a certain level is exceeded, bacteria respond with the initiation of a number of resistance mechanisms, including metallothioneins, P-type ATPases, CDF transporters and RND efflux pumps [54]. The genes located on plasmids, chromosomes or transposons that are responsible for resistance can easily be transferred to new community members from their point of location [53,55].

The genotype of bacteria, the nature and type of the metal and the $\mathrm{pH}$ of the culturing media are among the factors responsible for showing the degree of tolerance of microbes to various metals $(\mathrm{Hg}$, $\mathrm{Co}, \mathrm{Pb}, \mathrm{Ag}, \mathrm{Zn}, \mathrm{Mn}, \mathrm{Cu}, \mathrm{Cr}$ ) [56]. This kind of resistance against toxic heavy metals might be recognized by employing a number of potential methods like bioaccumulation of heavy metals by microbes, ion exclusion and low-molecular-weight binding protein production $[57,58]$. Elevated levels of metal resistance systems in bacterial cells are an indication of environmental heavy metal bioavailability [59]. The results of Chudobova et al. [60] showed a maximum resistance and capability of $S$. aureus strains under $\mathrm{Cd}^{2+}$ and $\mathrm{Zn}^{2+}$ ions. This resistance observed in S. aureus might be due to the efflux system containing a P-type ATPase transport system acting against $\mathrm{Cd}^{2+}$ ions $[53,61]$.

\subsection{Effect of S. aureus on Plant Growth Promotion under Cr Metal Stress}

Different wheat varieties may differ in their response to different concentration of $\mathrm{Cr}$ in the soil. This could be attributed to various biological aspects of wheat varieties, as different wheat varieties show differences in growth parameters (e.g., leaf size). A heavy metal like $\mathrm{Cr}$ can easily make its way to aerial portions of plants, where it will affect their shoot metabolism at the cellular level and cause severe damage to minerals, water and nutrients, consequently retarding plant growth $[10,62]$. 
However, bacterial inoculation may improve the nutritional requirements of both micro- $(\mathrm{Mn}, \mathrm{Zn}, \mathrm{Cu}$ and $\mathrm{Fe}$ ) and macronutrients (N, P and $\mathrm{K}$ ) by modifying host physiology, which results in changed uptake pattern of roots. Similarly, a recent investigation done by Islam et al. [63] showed an increase in $\mathrm{Fe}$ and $\mathrm{K}$ concentrations in maize plants under $\mathrm{Cr}$ stress due to bacterial inoculations. According to an observation, plants with bacterial inoculation showed a reduction in metal accumulation in their aerial parts, which might be due to delayed translocation of metals from roots to upper parts [64]. Similar observations were recorded in this current research. Moreover, we isolated S. aureus K1 from wastewater that was contaminated with $\mathrm{Cr}$, so the microbes may have the capability of performing metal detoxification as a part of their metabolic system. There was substantial improvement in plant growth and leaf pigments due to inoculation of specific microbes [63].

\subsection{Chlorophyll Contents}

Higher chlorophyll contents were observed in plants with bacterial inoculation compared to uninoculated plants (Figure 3). However, with further increasing metal concentrations, a reduction in chlorophyll contents was noted. This is in agreement with the findings of another research study, where chlorophyll a and chlorophyll $\mathrm{b}$ in wheat plants decreased with increasing concentrations of $\mathrm{Pb}$ in the growth medium [65].

\subsection{ROS Species and Antioxidant Enzyme Production}

Reactive oxygen species can be produced in plants when exposed to $\mathrm{Cr}^{6+}$, which may damage the photosynthetic apparatus and protein complex of thylakoid membranes and result in inhibition of chlorophyll production [66]. In adverse conditions, plants release MDA contents; this reveals the level of lipid peroxidation, as MDA is the last decomposition product of membrane lipid peroxidation [67]. The increase in MDA contents found in the present study is indicative of imbalance between the generation and removal of free radicals in the cells [68]. The decreased lipid peroxidation with S. aureus $\mathrm{K} 1$ inoculation under $\mathrm{Cr}$ stress could be due to the increase in ROS-scavenging enzyme production in plants. This may be supported by a previously published study which revealed that the gene profile of metal detoxifying enzymes was activated by bacterial inoculation to deal with metal stress [69]. Reactive oxygen species are generated in response to stress caused by heavy metals like hexavalent $\mathrm{Cr}$, and plants have a detoxifying antioxidant enzyme system for their maintenance. These enzymes are POD, SOD, $\mathrm{APX}$ and CAT, and they work alongside other non-enzymatic antioxidants. The activities performed by antioxidant enzymes in plants under metal stress are extremely variable and dependent on plant species, metal concentration, metal ions and exposure time period [70]. At low metal concentration, SOD activity may increase, but it becomes constant with increased metal concentration [71]. The enhancement in CAT activity was also noted in a number of plants under metal stress [72]. An increase in CAT activity was also observed as an adaptive trait of isolate CPSB21 [73]. Increased antioxidant enzyme activities in plants with inoculation of CPSB21 may be due to increases in mRNA/gene expression of antioxidant enzymes as compared to uninoculated plants [74].

\subsection{Reduction of $\mathrm{Cr}$ Concentration in Plants by Bacterial Inoculation}

A significant difference was found between uninoculated and S. aureus K1 inoculated plants in terms of $\mathrm{Cr}$ concentration. In contaminated soil, the results showed that the level of $\mathrm{Cr}$ was higher in the roots of wheat plants than it was in the shoots, which may be due to decreased translocation of $\mathrm{Cr}$ from roots to shoots of plants [75,76]. Immobilization of $\mathrm{Cr}$ in root cell vacuoles may lead to higher Cr accumulation in roots, which can cause toxicity in plants [77]. In the present study, inoculation of wheat plants with $\mathrm{Cr}$-resistant microbes decreased the $\mathrm{Cr}$ concentration and its translocation from soil to roots and upper parts of wheat plants. The reduction of hexavalent $\mathrm{Cr}\left(\mathrm{Cr}^{6+}\right)$ to trivalent $\mathrm{Cr}\left(\mathrm{Cr}^{3+}\right)$ by bacterial isolates may be the reason for the improved growth of wheat plants [78] and hence the decreased level of the $\mathrm{Cr}$ contents in soil. Hasnain and Sabri [79] also reported a pattern of decreased Cr uptake and accumulation in roots and shoots of wheat plants inoculated with Pseudomonas sp. 
A decrease in $\mathrm{Cr}$ concentration in soil was observed after wheat plant harvesting. This decrease was recorded in uninoculated $\mathrm{Cr}$-contaminated wheat plants as a result of increased accumulation and uptake of $\mathrm{Cr}$ in roots and shoots [80]. Such decrease may also be due to $\mathrm{Cr}^{6+}$ reduction into $\mathrm{Cr}^{3+}$ under the influence of bacterial inoculation $[78,81]$. Scientists are also considering the use genetically engineered microorganisms (GEM), which may be well adjusted to their local environment (both climatic and soil) for effective elimination of heavy metals from contaminated soils $[58,82,83]$.

\section{Conclusions}

The outcomes of this study indicate that the application of the peat-moss-based microbial inoculum improved plant growth and yield parameters and comparatively decreased metal accumulation by the plants. Overall, gas exchange attributes and chlorophyll contents increased with S. aureus K1 inoculation. This research study concluded that $S$. aureus $\mathrm{K} 1$ reduced the toxicity of $\mathrm{Cr}$ in wheat plants. The Cr-resistant S. aureus K1 supported the plant growth, decreased and detoxified $\mathrm{Cr}$ in plants and allowed better production of wheat in a Cr-contaminated environment. However, in-depth exploration (i.e., at the molecular level) of the alleviative mechanisms in plants should be conducted in future studies.

Author Contributions: F.Z., M.R., T.Y., S.A., M.A.E.-S., M.N.A. and L.W.; Data curation, M.Z., M.W., A.A. (Alia Anayat) and T.Y.; Formal analysis, M.Z., M.W., A.A. (Alia Anayat), M.R. and T.Y.; Funding acquisition, S.A., M.N.A. and L.W.; Investigation, M.R., A.A. (Awais Ahmad), T.Y. and M.A.E.-S.; Methodology, M.A., M.W., M.R., A.A. (Awais Ahmad), T.Y. and S.A.; Project administration, F.Z., T.Y. and S.A.; Resources, F.Z., M.W., S.A., M.A.E.-S., M.N.A. and L.W.; Software, F.Z., M.Z., M.A.E.-S. and L.W.; Supervision, M.R., T.Y. and S.A.; Validation, M.Z., M.W., A.A. (Alia Anayat) and A.A. (Awais Ahmad); Visualization, M.Z., M.W., A.A. (Alia Anayat) and A.A. (Awais Ahmad); Writing—original draft, F.Z., M.Z., S.A. and L.W.; Writing-review \& editing, F.Z., T.Y. and M.N.A. All authors have read and agreed to the published version of the manuscript.

Funding: This research was supported by the Higher Education Commission, Pakistan (grant number 20-3653/NRPU/R\&D/HEC/14/437). The authors would like to extend their sincere appreciation to the Researchers Supporting Project Number (RSP-2020/182), King Saud University, Riyadh, Saudi Arabia.

Acknowledgments: We are grateful to Government College University, Faisalabad, Pakistan, for its support. The authors would like to extend their sincere appreciation to the Researchers Supporting Project Number (RSP-2020/182), King Saud University, Riyadh, Saudi Arabia.

Conflicts of Interest: The authors declare that they have no conflict of interest.

\section{References}

1. Singh, H.P.; Mahajan, P.; Kaur, S.; Batish, D.R.; Kohli, R.K. Chromium toxicity and tolerance in plants. Environ. Chem. Lett. 2013, 11, 229-254. [CrossRef]

2. Kunjam, M. Studies on selected heavy metals on seed germination and plant growth in pea plant (Pisum sativum) grown in solid medium. J. Pharmacogn. Phytochem. 2015, 3, 85-87.

3. Habiba, U.; Ali, S.; Farid, M.; Shakoor, M.B.; Rizwan, M.; Ibrahim, M.; Abbasi, G.H.; Hayat, T.; Ali, B. EDTA enhanced plant growth, antioxidant defense system, and phytoextraction of copper by Brassica napus L. Environ. Sci. Pollut. Res. 2014, 22, 1534-1544. [CrossRef] [PubMed]

4. Adrees, M.; Ali, S.; Iqbal, M.; Bharwana, S.A.; Siddiqi, Z.; Farid, M.; Ali, Q.; Saeed, R.; Rizwan, M. Mannitol alleviates chromium toxicity in wheat plants in relation to growth, yield, stimulation of anti-oxidative enzymes, oxidative stress and $\mathrm{Cr}$ uptake in sand and soil media. Ecotoxicol. Environ. Saf. 2015, 122, 1-8. [CrossRef] [PubMed]

5. Mathur, S.; Kalaji, H.M.; Kalaji, H.M. Investigation of deleterious effects of chromium phytotoxicity and photosynthesis in wheat plant. Photosynthetica 2016, 54, 185-192. [CrossRef]

6. Kamran, M.A.; Mufti, R.; Mubariz, N.; Syed, J.H.; Bano, A.; Javed, M.T.; Munis, M.F.H.; Tan, Z.; Chaudhary, H.J. The potential of the flora from different regions of Pakistan in phytoremediation: A review. Environ. Sci. Pollut. Res. 2013, 21, 801-812. [CrossRef]

7. Daud, M.K.; Mei, L.; Variath, M.T.; Ali, S.; Li, C.; Rafiq, M.T.; Zhu, S.J. Chromium (VI) Uptake and Tolerance Potential in Cotton Cultivars: Effect on Their Root Physiology, Ultramorphology, and Oxidative Metabolism. BioMed Res. Int. 2014, 2014, 1-12. [CrossRef] 
8. Afshan, S.; Ali, S.; Bharwana, S.A.; Rizwan, M.; Farid, M.; Abbas, F.; Ibrahim, M.; Mehmood, M.A.; Abbasi, G.H. Citric acid enhances the phytoextraction of chromium, plant growth, and photosynthesis by alleviating the oxidative damages in Brassica napus L. Environ. Sci. Pollut. Res. 2015, 22, 11679-11689. [CrossRef]

9. Nagajyoti, P.C.; Lee, K.D.; Sreekanth, T.V.M. Heavy metals, occurrence and toxicity for plants: A review. Environ. Chem. Lett. 2010, 8, 199-216. [CrossRef]

10. Shanker, A. Chromium toxicity in plants. Environ. Int. 2005, 31, 739-753. [CrossRef]

11. Kamran, M.A.; Eqani, S.A.M.A.S.; Bibi, S.; Xu, R.-K.; Monis, M.F.H.; Katsoyiannis, A.; Bokhari, H.; Chaudhary, H.J. Bioaccumulation of nickel by E. sativa and role of plant growth promoting rhizobacteria (PGPRs) under nickel stress. Ecotoxicol. Environ. Saf. 2016, 126, 256-263. [CrossRef] [PubMed]

12. Dotaniya, M.L.; Das, H.; Meena, V.D. Assessment of chromium efficacy on germination, root elongation, and coleoptile growth of wheat (Triticum aestivum L.) at different growth periods. Environ. Monit. Assess. 2014, 186, 2957-2963. [CrossRef] [PubMed]

13. Lenka, S. Impacts of fertilizers use on environmental quality. In Proceedings of the National Seminar on Environmental Concern for Fertilizer Use in Future, Bidhan Chandra Krishi Viswavidyalaya, Kalyani, India, 26 February 2016.

14. Saha, J.; Selladurai, R.; Coumar, M.V.; Dotaniya, M.L.; Kundu, S.; Patra, A.K. Industrial Activities in India and Their Impact on Agroecosystem; Springer Science and Business Media LLC: Berlin/Heidelberg, Germany, 2017; Volume 10, pp. 229-249.

15. Khan, M.Y. Effect of microbial inoculation on wheat growth and phytostabilization of chromium contaminated soil. Pak. J. Bot. 2013, 45, 27-34.

16. Rizwan, M.; Ali, S.; Abbas, T.; Zia-Ur-Rehman, M.; Hannan, F.; Keller, C.; Al-Wabel, M.I.; Ok, Y.S. Cadmium minimization in wheat: A critical review. Ecotoxicol. Environ. Saf. 2016, 130, 43-53. [CrossRef] [PubMed]

17. Shewry, P.R.; Hey, S.J. The contribution of wheat to human diet and health. Food Energy Secur. 2015, 4, 178-202. [CrossRef]

18. Awan, N.; Fatima, A.; Farhan, M.; Awan, N. Comparative Analysis of Chromium and Cadmium in Various Parts of Wheat and Maize. Pol. J. Environ. Stud. 2019, 28, 1561-1566. [CrossRef]

19. Carlin, D.J.; Naujokas, M.F.; Bradham, K.D.; Cowden, J.; Heacock, M.; Henry, H.F.; Lee, J.S.; Thomas, D.J.; Thompson, C.; Tokar, E.J.; et al. Arsenic and Environmental Health: State of the Science and Future Research Opportunities. Environ. Health Perspect. 2016, 124, 890-899. [CrossRef]

20. Abbas, Q.; Yousaf, B.; Liu, G.; Zia-Ur-Rehman, M.; Ali, M.U.; Munir, M.A.M.; Hussain, S.A. Evaluating the health risks of potentially toxic elements through wheat consumption in multi-industrial metropolis of Faisalabad, Pakistan. Environ. Sci. Pollut. Res. 2017, 24, 26646-26657. [CrossRef]

21. Lytle, C.M.; Lytle, F.W.; Yang, N.; Qian, J.-H.; Hansen, D.; Zayed, A.; Terry, N. Reduction of Cr(VI) to Cr(III) by Wetland Plants: Potential for In Situ Heavy Metal Detoxification. Environ. Sci. Technol. 1998, 32, 3087-3093. [CrossRef]

22. Mishra, J.; Singh, R.; Arora, N.K. Alleviation of Heavy Metal Stress in Plants and Remediation of Soil by Rhizosphere Microorganisms. Front. Microbiol. 2017, 8, 1706. [CrossRef]

23. Ashraf, S.; Ali, Q.; Zahir, Z.A.; Ashraf, S.; Asghar, H.N. Phytoremediation: Environmentally sustainable way for reclamation of heavy metal polluted soils. Ecotoxicol. Environ. Saf. 2019, 174, 714-727. [CrossRef] [PubMed]

24. Kong, Z.; Glick, B.R. The Role of Plant Growth-Promoting Bacteria in Metal Phytoremediation; Elsevier: Amsterdam, The Netherlands, 2017; pp. 97-132.

25. Ryan, R.P.; Monchy, S.; Cardinale, M.; Taghavi, S.; Crossman, L.; Avison, M.B.; Berg, G.; Van Der Lelie, D.; Dow, J.M. The versatility and adaptation of bacteria from the genus Stenotrophomonas. Nat. Rev. Genet. 2009, 7, 514-525. [CrossRef] [PubMed]

26. Taj, Z.Z.; Rajkumar, M. Perspectives of Plant Growth-Promoting Actinomycetes in Heavy Metal Phytoremediation; Springer Science and Business Media LLC: Berlin/Heidelberg, Germany, 2016; pp. 213-231.

27. Mishra, S.; Bharagava, R.N. Toxic and genotoxic effects of hexavalent chromium in environment and its bioremediation strategies. J. Environ. Sci. Health Part C 2015, 34, 1-32. [CrossRef] [PubMed]

28. Wirtanen, G.; Salo, S. Biofilm risks. In Handbook of Hygiene Control in the Food Industry; Elsevier: Amsterdam, The Netherlands, 2016; pp. 55-79. 
29. Ahemad, M. Enhancing phytoremediation of chromium-stressed soils through plant-growth-promoting bacteria. J. Genet. Eng. Biotechnol. 2015, 13, 51-58. [CrossRef]

30. Jing, Y.X.; Yan, J.L.; He, H.D.; Yang, D.J.; Xiao, L.; Zhong, T.; Yuan, M.; De Cai, X.; Bin Li, S. Characterization of Bacteria in the Rhizosphere Soils ofPolygonum Pubescensand Their Potential in Promoting Growth and $\mathrm{Cd}, \mathrm{Pb}, \mathrm{Zn}$ Uptake byBrassica napus. Int. J. Phytoremediation 2013, 16, 321-333. [CrossRef]

31. Mukhtar, S. Potential of sunflower (Helianthus annuus L.) for phytoremediation of nickel (Ni) and lead (Pb) contaminated water. Pak. J. Bot. 2010, 42, 4017-4026.

32. Soltanpour, P.N. Use of ammonium bicarbonate DTPA soil test to evaluate elemental availability and toxicity 1. Commun. Soil Sci. Plant Anal. 1985, 16, 323-338. [CrossRef]

33. Moodie, C.D.; Smith, H.W.; McCreery, R.A. Laboratory Manual for Soil Fertility. Soil Sci. 1951, 71, 400. [CrossRef]

34. Lucious, S. Heavy metal tolerance and antibiotic sensitivity of bacterial strains isolated from tannery effluent. Asian J. Exp. Biol. Sci. 2013, 4, 597-606.

35. Zhang, X.; Krumholz, L.R.; Yu, Z.; Chen, Y.; Liu, P.; Li, X. A Novel Subspecies of Staphylococcus aureus from Sediments of Lanzhou Reach of the Yellow River Aerobically Reduces Hexavalent Chromium. J. Bioremediation Biodegrad. 2013, 4. [CrossRef]

36. Turner, S.; Pryer, K.M.; Miao, V.P.W.; Palmer, J.D. Investigating deep phylogenetic relationships among cyanobacteria and plastids by small subunit rRNA sequence analysis. J. Eukaryot. Microbiol. 1999, 46, 327-338. [CrossRef] [PubMed]

37. Moyersoen, B.; E Beever, R.; Martin, F. Genetic diversity of Pisolithus in New Zealand indicates multiple long-distance dispersal from Australia. New Phytol. 2003, 160, 569-579. [CrossRef]

38. Tamura, K.; Peterson, D.; Stecher, G.; Nei, M.; Kumar, S.; Peterson, N. MEGA5: Molecular Evolutionary Genetics Analysis Using Maximum Likelihood, Evolutionary Distance, and Maximum Parsimony Methods. Mol. Boil. Evol. 2011, 28, 2731-2739. [CrossRef] [PubMed]

39. Hadi, F.; Bano, A. Effect of diazotrophs (Rhizobium and Azatebactor) on growth of maize (Zea mays L.) and accumulation of lead $(\mathrm{Pb})$ in different plant parts. Pak. J. Bot. 2010, 42, 4363-4370.

40. Wu, S.; Cheung, K.; Luo, Y.; Wong, M.H. Effects of inoculation of plant growth-promoting rhizobacteria on metal uptake by Brassica juncea. Environ. Pollut. 2006, 140, 124-135. [CrossRef] [PubMed]

41. Lichtenthaler, H.K. Chlorophylls and carotenoids: Pigments of photosynthetic biomembranes. In Methods in Enzymology; Elsevier: Amsterdam, The Netherlands, 1987; pp. 350-382.

42. Dionisio-Sese, M.L.; Tobita, S. Antioxidant responses of rice seedlings to salinity stress. Plant Sci. 1998, 135, 1-9. [CrossRef]

43. Plumb-Dhindsa, P.; Dhindsa, R.S.; Thorpe, T.A. Leaf Senescence: Correlated with Increased Levels of Membrane Permeability and Lipid Peroxidation, and Decreased Levels of Superoxide Dismutase and Catalase. J. Exp. Bot. 1981, 32, 93-101. [CrossRef]

44. Zhang, J.; Kirkham, M. Drought-Stress-Induced Changes in Activities of Superoxide Dismutase, Catalase, and Peroxidase in Wheat Species. Plant Cell Physiol. 1994, 35, 785-791. [CrossRef]

45. Jana, S.; Choudhuri, M.A. Glycolate metabolism of three submersed aquatic angiosperms: Effect of heavy metals. Aquat. Bot. 1981, 11, 67-77. [CrossRef]

46. Zhang, X. The measurement and mechanism of lipid peroxidation and SOD, POD and CAT activities in biological system. In Research Methodology of Crop Physiology; Agriculture Press: Beijing, China, 1992; pp. 208-211.

47. Aebi, H. Catalase in vitro. Methods Enzym. 1984, 105, 121-126.

48. Nakano, Y.; Asada, K. Hydrogen Peroxide is Scavenged by Ascorbate-specific Peroxidase in Spinach Chloroplasts. Plant Cell Physiol. 1981, 22, 867-880. [CrossRef]

49. Rehman, M.Z.-U.; Rizwan, M.; Ghafoor, A.; Naeem, A.; Ali, S.; Sabir, M.; Qayyum, M.F. Effect of inorganic amendments for in situ stabilization of cadmium in contaminated soils and its phyto-availability to wheat and rice under rotation. Environ. Sci. Pollut. Res. 2015, 22, 16897-16906. [CrossRef] [PubMed]

50. Khan, Z.; Nisar, M.A.; Hussain, S.Z.; Arshad, M.N.; Rehman, A. Cadmium resistance mechanism in Escherichia coli P4 and its potential use to bioremediate environmental cadmium. Appl. Microbiol. Biotechnol. 2015, 99, 10745-10757. [CrossRef] [PubMed] 
51. Oaikhena, E.E.; Makaije, D.B.; Denwe, S.D.; Namadi, M.M.; Haroun, A.A. Bioremediation Potentials of Heavy Metal Tolerant Bacteria Isolated from Petroleum Refinery Effluent. Am. J. Environ. Prot. 2016, 5, 29. [CrossRef]

52. Mustapha, M.U.; Halimoon, N. Screening and Isolation of Heavy Metal Tolerant Bacteria in Industrial Effluent. Procedia Environ. Sci. 2015, 30,33-37. [CrossRef]

53. Bruins, M.R.; Kapil, S.; Oehme, F.W. Microbial Resistance to Metals in the Environment. Ecotoxicol. Environ. Saf. 2000, 45, 198-207. [CrossRef]

54. Nies, D.H. Efflux-mediated heavy metal resistance in prokaryotes. FEMS Microbiol. Rev. 2003, 27, 313-339. [CrossRef]

55. Sørensen, S.J.; Bailey, M.; Hansen, L.H.; Kroer, N.; Wuertz, S. Studying plasmid horizontal transfer in situ: A critical review. Nat. Rev. Genet. 2005, 3, 700-710. [CrossRef]

56. Kashif, M.; Ngaini, Z.; Harry, A.V.; Vekariya, R.L.; Ahmad, A.; Zuo, Z.; Alarifi, A. An experimental and DFT study on novel dyes incorporated with natural dyes on titanium dioxide $\left(\mathrm{TiO}_{2}\right)$ towards solar cell application. Appl. Phys. A 2020, 126, 1-13. [CrossRef]

57. Nies, D.H. Microbial heavy-metal resistance. Appl. Microbiol. Biotechnol. 1999, 51, 730-750. [CrossRef]

58. Das, S.; Dash, H.R.; Chakraborty, J. Genetic basis and importance of metal resistant genes in bacteria for bioremediation of contaminated environments with toxic metal pollutants. Appl. Microbiol. Biotechnol. 2016, 100, 2967-2984. [CrossRef] [PubMed]

59. Roosa, S.; Wattiez, R.; Prygiel, E.; Lesven, L.; Billon, G.; Gillan, D.C. Bacterial metal resistance genes and metal bioavailability in contaminated sediments. Environ. Pollut. 2014, 189, 143-151. [CrossRef] [PubMed]

60. Chudobova, D.; Dostalova, S.; Ruttkay-Nedecký, B.; Guran, R.; Rodrigo, M.A.M.; Tmejová, K.; Krizkova, S.; Zitka, O.; Adam, V.; Kizek, R. The effect of metal ions on Staphylococcus aureus revealed by biochemical and mass spectrometric analyses. Microbiol. Res. 2015, 170, 147-156. [CrossRef]

61. Nies, D.H.; Silver, S.D. Ion efflux systems involved in bacterial metal resistances. J. Ind. Microbiol. Biotechnol. 1995, 14, 186-199. [CrossRef] [PubMed]

62. Chatterjee, J.; Kumar, P.; Sharma, P.N.; Tewari, R.K. Chromium toxicity induces oxidative stress in turnip. Indian J. Plant Physiol. 2015, 20, 220-226. [CrossRef]

63. Islam, F.; Yasmeen, T.; Arif, M.S.; Riaz, M.; Shahzad, S.M.; Imran, Q.; Ali, I. Combined ability of chromium $(\mathrm{Cr})$ tolerant plant growth promoting bacteria (PGPB) and salicylic acid (SA) in attenuation of chromium stress in maize plants. Plant Physiol. Biochem. 2016, 108, 456-467. [CrossRef]

64. Islam, F.; Yasmeen, T.; Ali, Q.; Ali, S.; Arif, M.S.; Hussain, S.; Rizvi, H. Influence of Pseudomonas aeruginosa as PGPR on oxidative stress tolerance in wheat under Zn stress. Ecotoxicol. Environ. Saf. 2014, 104, 285-293. [CrossRef]

65. Lamhamdi, M.; El Galiou, O.; Bakrim, A.; Nóvoa-Muñoz, J.C.; Arias-Estévez, M.; Aarab, A.; Lafont, R. Effect of lead stress on mineral content and growth of wheat (Triticum aestivum) and spinach (Spinacia oleracea) seedlings. Saudi J. Boil. Sci. 2013, 20, 29-36. [CrossRef]

66. Oliveira, H. Chromium as an Environmental Pollutant: Insights on Induced Plant Toxicity. J. Bot. 2012, 2012, 1-8. [CrossRef]

67. Arif, M.S.; Yasmeen, T.; Shahzad, S.M.; Riaz, M.; Rizwan, M.; Iqbal, S.; Asif, M.; Soliman, M.H.; Ali, S. Lead toxicity induced phytotoxic effects on mung bean can be relegated by lead tolerant Bacillus subtilis (PbRB3). Chemosphere 2019, 234, 70-80. [CrossRef]

68. Sytar, O.; Kumar, A.; Latowski, D.; Kuczyńska, P.; Strzałka, K.; Prasad, M.N.V. Heavy metal-induced oxidative damage, defense reactions, and detoxification mechanisms in plants. Acta Physiol. Plant. 2012, 35, 985-999. [CrossRef]

69. Islam, F.; Yasmeen, T.; Ali, Q.; Mubin, M.; Ali, S.; Arif, M.S.; Hussain, S.; Riaz, M.; Abbas, F. Copper-resistant bacteria reduces oxidative stress and uptake of copper in lentil plants: Potential for bacterial bioremediation. Environ. Sci. Pollut. Res. 2015, 23, 220-233. [CrossRef]

70. Sharma, S.S.; Dietz, K.-J. The relationship between metal toxicity and cellular redox imbalance. Trends Plant Sci. 2009, 14, 43-50. [CrossRef] [PubMed]

71. Štolfa, I.; Pfeiffer, T.Z.; Špoljarić, D.; Teklić, T.; Lončarić, Z. Heavy Metal-Induced Oxidative Stress in Plants: Response of the Antioxidative System; Springer Science and Business Media LLC: Berlin/Heidelberg, Germany, 2015; pp. 127-163. 
72. Fayiga, A.O.; Ma, L.Q.; Cao, X.; Rathinasabapathi, B. Effects of heavy metals on growth and arsenic accumulation in the arsenic hyperaccumulator Pteris vittata L. Environ. Pollut. 2004, 132, 289-296. [CrossRef] [PubMed]

73. Vital, S.A.; Fowler, R.W.; Virgen, A.; Gossett, D.R.; Banks, S.W.; Rodriguez, J. Opposing roles for superoxide and nitric oxide in the $\mathrm{NaCl}$ stress-induced upregulation of antioxidant enzyme activity in cotton callus tissue. Environ. Exp. Bot. 2008, 62, 60-68. [CrossRef]

74. Gururani, M.A.; Upadhyaya, C.P.; Baskar, V.; Venkatesh, J.; Nookaraju, A.; Park, S.W. Plant Growth-Promoting Rhizobacteria Enhance Abiotic Stress Tolerance in Solanum tuberosum Through Inducing Changes in the Expression of ROS-Scavenging Enzymes and Improved Photosynthetic Performance. J. Plant Growth Regul. 2012, 32, 245-258. [CrossRef]

75. Huffman, E.W.D.; Allaway, W.H. Chromium in plants. Distribution in tissues, organelles, and extracts and availability of bean leaf chromium to animals. J. Agric. Food Chem. 1973, 21, 982-986. [CrossRef]

76. Zayed, A.; Lytle, C.M.; Qian, J.-H.; Terry, N. Chromium accumulation, translocation and chemical speciation in vegetable crops. Planta 1998, 206, 293-299. [CrossRef]

77. Shanker, A.; Djanaguiraman, M.; Sudhagar, R.; Chandrashekar, C.; Pathmanabhan, G. Differential antioxidative response of ascorbate glutathione pathway enzymes and metabolites to chromium speciation stress in green gram ((L.) R.Wilczek. cv CO 4) roots. Plant Sci. 2004, 166, 1035-1043. [CrossRef]

78. Salunkhe, P.; Dhakephalkar, P.; Paknikar, K.M. Bioremediation of hexavalent chromium in soil microcosms. Biotechnol. Lett. 1998, 20, 749-751. [CrossRef]

79. Hasnain, S.; Sabri, A.N. Growth stimulation of Triticum aestivum seedlings under Cr-stresses by non-rhizospheric pseudomonad strains. Environ. Pollut. 1997, 97, 265-273. [CrossRef]

80. Mishra, S.; Shanker, K.; Srivastava, M.; Srivastava, S.; Shrivastav, R.; Dass, S.; Prakash, S. A study on the uptake of trivalent and hexavalent chromium by paddy (Oryza sativa): Possible chemical modifications in rhizosphere. Agric. Ecosyst. Environ. 1997, 62, 53-58. [CrossRef]

81. Cheung, K.H.; Gu, J.-D. Reduction of chromate (CrO42-) by an enrichment consortium and an isolate of marine sulfate-reducing bacteria. Chemosphere 2003, 52, 1523-1529. [CrossRef]

82. Gupta, S.; Singh, D. Role of Genetically Modified Microorganisms in Heavy Metal Bioremediation. In Advances in Environmental Biotechnology; Springer Science and Business Media LLC: Berlin/Heidelberg, Germany, 2017; Volume 3, pp. 197-214.

83. Ali, B.; Wang, B.; Ali, S.; Ghani, M.A.; Hayat, M.T.; Yang, C.; Xu, L.; Zhou, W. 5-Aminolevulinic Acid Ameliorates the Growth, Photosynthetic Gas Exchange Capacity, and Ultrastructural Changes Under Cadmium Stress in Brassica napus L. J. Plant Growth Regul. 2013, 32, 604-614. [CrossRef] 